\title{
Morpho-agronomic characterization of sweet potato germplasm
}

\author{
Rodrigo P Alves; Arie F Blank; Alisson Marcel S Oliveira; Aléa Dayane D Santana; Vanderson S Pinto; \\ Thiago M Andrade
}

Universidade Federal de Sergipe (UFS), São Cristóvão-SE, Brasil; afblank@ufs.br

\begin{abstract}
Sweet potato (Ipomoea batatas) spreads mainly by vegetative propagation, and therefore this vegetable may have duplicate accessions in germplasm banks. The authors aimed to characterize morpho-agronomically the sweet potato germplasm from the Active Germplasm Bank (AGB) of Universidade Federal de Sergipe (UFS). The experiment was carried out at the Research Farm "Campus Rural da UFS". The experimental design was a randomized block design, testing 73 sweet potato accessions with two replicates and four plants per plot. Morpho-agronomic traits of aboveground part and roots were evaluated. We observed that the leaf lobe type, the number of lobes per leaf, shape of central lobe, and general leaf shape were traits which provided the most variability among the accessions. For damage caused by soil insects, 52 accessions showed tolerance. The accessions presented a range from 0.33 to $2.71 \mathrm{t} /$ ha for dry mass of aboveground part and from 1.20 to $10.89 \mathrm{t} / \mathrm{h}$ a for the total productivity of the roots. The high phenotypic variability of this crop shows good prospect for breeding programs.
\end{abstract}

Keywords: Ipomoea batatas, resistance, diversity, descriptors, productivity.

\begin{abstract}
RESUMO
Caracterização morfo-agronômica de germoplasma de batata-doce

A batata-doce (Ipomoea batatas) se propaga essencialmente por multiplicação vegetativa, e por isso pode apresentar acessos duplicados em bancos de germoplasma. O objetivo do presente trabalho foi realizar a caracterização morfológica e agronômica de germoplasma de batata-doce do Banco Ativo de Germoplasma (BAG) da Universidade Federal de Sergipe (UFS). O experimento foi conduzido na Fazenda Experimental "Campus Rural da UFS". O delineamento experimental utilizado foi de blocos casualizados, testando 73 acessos de batata-doce, com duas repetições e quatro plantas por parcela. Foram avaliadas características morfológicas e agronômicas da parte aérea e das raízes. Observou-se que o tipo de lóbulo da folha, o número de lóbulos por folha, a forma do lóbulo central e a forma geral da folha foram as características que mais proporcionaram variabilidade entre os acessos. Para danos causados por insetos de solo, 52 acessos apresentaram-se como tolerantes. Os acessos apresentaram variação entre 0,33 e 2,71 t/ha, para massa seca da parte aérea, e entre 1,20 a 10,89 t/ha, para produtividade total de raízes, e de maneira geral, os acessos apresentaram grande variabilidade fenotípica apontando perspectivas para um programa de melhoramento genético desta cultura.
\end{abstract}

Palavras-chave: Ipomoea batatas, resistência, diversidade, descritores, produtividade.

\section{Received on June 10, 2016; accepted on April 13, 2017}

$\mathrm{S}$ weet potato (Ipomoea batatas) is a plant cultivated worldwide, where water availability is enough to support its growth (Salawu \& Mukhtar, 2008). Besides the economic and social importance, it is source of food supplement for population living in poverty areas, since it is rich in carbohydrates and also highly energetic (Camargo, 2013).

This vegetable is easy to cultivate, rustic and widely adapted to different types of soil and climate, with high tolerance to dry weather and low production cost. Sweet potato is widely used in human diet and animal feed and as raw material in food, fabric, paper, cosmetics, adhesive preparation and fuel alcohol industries (Gonçalves Neto et al., 2011).

The world's largest producer of sweet potatoes is China, producing $3,685,254 \mathrm{t} /$ year reaching average productivity of $23.1 \mathrm{t} / \mathrm{ha}$ (FAO, 2010). Brazil has an annual productivity of 12.8 $\mathrm{t} /$ ha, considering that Rio Grande do Sul is the largest producer, with $166,354 \mathrm{t}$ and productivity of $13.4 \mathrm{t} / \mathrm{ha}$. The State of Sergipe contributes with 44,397 t, considering to be the largest producer in the Northeast part of Brazil with productivity of $14.3 \mathrm{t} / \mathrm{ha}$ (IBGE, 2013).

The sweet potato shows high genetic variability, however, changes in consumption habit and lack of researches have been contributing to the loss of important genotypes. Due to this fact, the autors justify the importance of maintaining this species in germplasm banks (Figueiredo, 2010).

Morphological markers are very accessible descriptors for quantifying the phenotypic diversity when compared to more advanced molecular techniques, and these markers have been used by several authors in Brazil and in the world, allowing some authors carrying out studies with more sophisticated descriptors, such as the molecular markers (Fabri, 2009).

The agronomic characterization 
provides information for sweet potato breeding, for commercial cultivation and to determine the use of the accessions. These descriptors take into consideration desirable traits which meet the market demandings. For sweet potato, these traits are total and commercial productivity, adaptability and stability of accessions in a particular growing region, occurrence of skin defects, resistance to pests, among others (Camargo, 2013).

Given the above, the authors aimed to characterize morpho-agronomically the Sweet Potato Germplasm Bank of Universidade Federal de Sergipe.

\section{MATERIAL AND METHODS}

The experiment was carried out from March to August, 2012 on the Experimental Farm "Campus Rural da Universidade Federal de Sergipe", located at municipality of São CristóvãoSE (1055'27'S, 37 $12^{\circ}$ '01' $\mathrm{W}$, altitude $46 \mathrm{~m})$. The soil is classified as Red Yellow Latosol, being the landscape flat to nearly flattened. The region has a semi-arid tropical climate, mild summer and wet winter, hot and dry, according to the National Institute of Meteorology (www.inmet.gov.br/projetos/rede/ pesquisa/) the average rainfall and the lowest and the highest temperature were $17.8 \mathrm{~mm}, 24.4^{\circ} \mathrm{C}, 30.6^{\circ} \mathrm{C}$ in March, 24.5 $\mathrm{mm}, 24.5^{\circ} \mathrm{C}, 30.6^{\circ} \mathrm{C}$ in April; 144.6 $\mathrm{mm}, 23.4^{\circ} \mathrm{C}, 29.9^{\circ} \mathrm{C}$ in May; 118.0 $\mathrm{mm}, 22.7^{\circ} \mathrm{C}, 28.9^{\circ} \mathrm{C}$ in June; 100.0 $\mathrm{mm}, 22.3^{\circ} \mathrm{C}, 28.3^{\circ} \mathrm{C}$ in July; $77.1 \mathrm{~mm}$, $22.2^{\circ} \mathrm{C}, 28.1^{\circ} \mathrm{C}$ in August, respectively.

The used plant material consisted of accesions of sweet potato of the Germplasm Bank of UFS, considering fifty eight accessions of the Germplasm Bank of UFLA (IPB-001, IPB-002, IPB-006, IPB-007, IPB-011, IPB-013, IPB-014, IPB-016, IPB-023, IPB-026, IPB-027, IPB-030, IPB-036, IPB-037, IPB-038, IPB-042, IPB-043, IPB-047, IPB-052, IPB-053, IPB-054, IPB-056, IPB-059, IPB-060, IPB-063, IPB-065, IPB-067, IPB-071, IPB-072, IPB-073, IPB-075, IPB-077, IPB-078, IPB-079, IPB-087, IPB-089, IPB-090, IPB-091,
IPB-093, IPB-098, IPB-099, IPB-101, IPB-103, IPB-105, IPB-108, IPB-109, IPB-113, IPB-114, IPB-117, IPB-120, IPB-121, IPB-123, IPB-126, IPB-127, IPB-134, IPB-136, IPB-137 and IPB144), two accessions from Malhador-SE (IPB-145 and IPB-146), six from Moita Bonita-SE (IPB-147, IPB-148, IPB-149, IPB-150, IPB-151 and IPB-153), four accessions from Remijo-PB (IPB-154, IPB-155, IPB-157 and IPB-158) and three accessions from Heliópolis-BA (IPB-095, IPB-159 and IPB-160), totalizing seventy three accessions.

Before soil preparation, soil samples were collected from the 0-20 cm layer, for chemical-physical analysis, and the results were: $\mathrm{pH}\left(\mathrm{H}_{2} \mathrm{O}\right)=5.40$; organic matter $=0.86 \mathrm{dag} / \mathrm{dm}^{3} ; \mathrm{Ca}^{+2}+=0.82$ $\mathrm{cmol}_{\mathrm{c}} / \mathrm{dm}^{3} ; \mathrm{Mg}^{+2}=0.43 \mathrm{cmol}_{\mathrm{c}} / \mathrm{dm}^{3} ; \mathrm{Al}^{+3}=$ $0.65 \mathrm{cmol}_{\mathrm{c}} / \mathrm{dm}^{3} ; \mathrm{H}+\mathrm{Al}=2.03 \mathrm{cmol}_{\mathrm{c} /} \mathrm{dm}^{3}$; $\mathrm{Na}=3.5 \mathrm{mg} / \mathrm{dm}^{3} ; \mathrm{K}=21.1 \mathrm{mg} / \mathrm{dm}^{3}$; $\mathrm{P}=7.0 \mathrm{mg} / \mathrm{dm}^{3} ; \mathrm{SB}=0.89 \mathrm{cmol}_{\mathrm{c}} / \mathrm{dm}^{3}$; $\mathrm{CTC}=2.92 \mathrm{cmol}_{\mathrm{c}} / \mathrm{dm}^{3}$; Sand $=738.2 \mathrm{~g} /$ $\mathrm{kg}$; Clay= $54.6 \mathrm{~g} / \mathrm{kg}$; Silt= $207.2 \mathrm{~g} / \mathrm{kg}^{1}$; Textural classification $=$ Sandy loam.

Liming was carried out thirty days after planting based on the results of the soil analysis. According to Filgueira (2008), fertilization consisted of $20 \mathrm{~kg} / \mathrm{ha}$ of $\mathrm{N} ; 90 \mathrm{~kg} /$ ha of $\mathrm{P}_{2} \mathrm{O}_{5} ; 90 \mathrm{~kg} /$ ha of $\mathrm{K}_{2} \mathrm{O}$. At 45 days after planting, the authors carried out the top dressing, applying 30 $\mathrm{kg} / \mathrm{ha}$ of $\mathrm{N}, 40 \mathrm{~kg} / \mathrm{ha}$ of $\mathrm{P}_{2} \mathrm{O}_{5}$ and $60 \mathrm{~kg} /$ ha of $\mathrm{K}_{2} \mathrm{O}$. The supplementary cultural management during the conduction of the experiment was carried out according to recommendations for sweet potato (Filgueira, 2008).

The experimental design was randomized blocks, with seventy three treatments and two replicates, with four plants per plot, spacing used was $1.0 \mathrm{x}$ $0.3 \mathrm{~m}$. The authors used vines containing from eight to twelve internodes, $25-\mathrm{cm}$ length, burying the basal part of the vine, containing three-four internodes, at 10$15 \mathrm{~cm}$ depth in windrows of 40-cm high.

The morphological characterization of the above ground part was carried out at 120 days after the vine planting. The vegetative parts were evaluated using the following 15 descriptors (Huamán, 1992): growth habit, internode length, predominant vine color, secondary vine color, general leaf shape, leaf lobe types, leaf lobe number, general leaf shape, central lobe shape, mature leaf size, leaf vein pigmentation, mature leaf color, immature leaf color, petiole pigmentation and petiole length.

The root morphological characterization was carried out at 150 days after the planting of vines, during the harvest. The roots were evaluated, according to Huamán (1992), using 7 descriptors: root shape, root surface defects, predominant pellicle color, predominant pellicle color intensity, secondary pellicle color, predominant flesh color and secondary flesh color.

The agronomic characterization was carried out using the descriptors: shoot fresh mass, in which the vines were cut, identified and weighed, being the results expressed in $\mathrm{t} / \mathrm{ha}$. After weighing, the vines were kept in paper bags and placed in oven with forced air circulation at a temperature of $65^{\circ} \mathrm{C}$ until constant weight, the results were expressed in $\mathrm{t} / \mathrm{ha}$. The total productivity of the roots was obtained weighing all the roots of the plot and having their productivity estimated in $\mathrm{t} / \mathrm{ha}$.

The classification of sweet potatoes in relation to damage caused by soil insects was carried out using the rating scale, established by França \& Ritschel (2002), ranging from 1 to 5 , in which " 1 " represents damage-free roots, suitable for market; " 2 " roots showing little damage, losing a little regarding to the commercial aspect (presence of some galleries and holes in the roots); "3" roots showing damages which are easy to be noticed (presence of some galleries and holes in the roots in greater intensity), unsuitable for market; " 4 " highly damaged roots, practically unsuitable for the market (presence of many galleries, and early rot holes); and " 5 " roots completely unsuitable for commercial purposes (full of galleries, holes and in an advanced stage of rotting).

Data were submitted to variance analysis and the averages compared by Scott-Knott test $\mathrm{p} \leq 0.05$, using the statistical program SISVAR (Ferreira, 2011). To estimate the phenotypic diversity, multivariate analysis was carried out using principal component 
analysis using the computer program STATISTICA version 7.0.

\section{RESULTS AND DISCUSSION}

The authors observed differences for the evaluated accessions regarding all morphological variables, both for shoot and $\operatorname{root}(\mathrm{p} \leq 0.01)$.

The average of the morphological characterization data showed that a variation among twenty one qualitative traits of sweet potato was noticed. The variables which showed little morphological variability were: mature leaf size, $80.8 \%$ of the accessions presented average size of $8-15 \mathrm{~cm}$, mature leaf color, which presented yellowish-green color in $83.9 \%$ of the accessions, secondary pellicle color, $78.1 \%$ of the accessions presenting absence of color, and secondary flesh color, $97.3 \%$ of absent-color accessions.

For growth habit, $15.1 \%$ of the accessions showed erect vine, $41.1 \%$ semi-erect vine, $39.7 \%$ spreading and $4.1 \%$ extremely spreading. In relation to the internode length, $23.3 \%$ resulted in very short internode, $56.2 \%$ short, $19.2 \%$ intermediate and only $1.3 \%$ showed to be long. The predominant color of green vine appeared in $6.9 \%$ of the accessions, $41.1 \%$ of the accessions showed green vines with few purple spots, $15.1 \%$ green vines with many purple spots, $8.2 \%$ green vines with many dark purple spots, $20.6 \%$ mostly purple vines, $2.7 \%$ mostly dark purple vines, $4.1 \%$ totally purple vines and $1.3 \%$ totally dark purple vines. For the secondary vine color, the authors observed $20.6 \%$ with green tip, $34.2 \%$ with purple base, $4.1 \%$ with purple tip, $27.4 \%$ with purple internodes and $13.7 \%$ showed other colors. The authors also verified that $27.4 \%$ of the accessions showed cordate leaves, $49.3 \%$ triangular leaves, $4.1 \%$ hastate leaves and 19.2\% lobed leaves. In relation to the leaf lobe type, $68.5 \%$ of the accessions showed lateral lobes, $6.8 \%$ showed moderate lobes and 5.5\% showed deeb lobes. For the number of leaf lobes, $72.6 \%$ of the accessions showed one lobe, $8.2 \%$ three lobes and $19.2 \%$ five lobes. In relation to the shape of central leaf lobe $57.6 \%$,
Table 1. Damages caused by soil insects, fresh and dry masses of the shoot and total root productivity of 73 sweet potato accessions from the Active Germplasm Bank of Universidade Federal de Sergipe. São Cristóvão, UFS, 2012.

\begin{tabular}{|c|c|c|c|c|}
\hline \multirow[t]{2}{*}{ Accession } & \multirow{2}{*}{$\begin{array}{c}\text { Damages caused } \\
\text { by soil insects } \\
\text { (note } 1-5)\end{array}$} & $\begin{array}{c}\text { Shoot fresh } \\
\text { mass }\end{array}$ & $\begin{array}{l}\text { Shoot dry } \\
\text { mass }\end{array}$ & $\begin{array}{c}\text { Total root } \\
\text { productivity }\end{array}$ \\
\hline & & \multicolumn{3}{|c|}{ (t/ha) } \\
\hline IPB-001 & $1.39 \mathrm{a}$ & $3.54 \mathrm{c}$ & $0.91 \mathrm{~d}$ & $6.05 \mathrm{~b}$ \\
\hline IPB-002 & $1.73 \mathrm{a}$ & $2.66 \mathrm{~d}$ & $0.79 \mathrm{e}$ & $4.63 \mathrm{c}$ \\
\hline IPB-006 & $1.74 \mathrm{a}$ & $8.58 \mathrm{~b}$ & $2.21 \mathrm{~b}$ & $9.72 \mathrm{a}$ \\
\hline IPB-007 & $3.43 \mathrm{c}$ & $4.42 \mathrm{c}$ & $1.25 \mathrm{~d}$ & $6.47 \mathrm{~b}$ \\
\hline IPB-011 & $3.14 \mathrm{c}$ & $10.16 \mathrm{a}$ & $1.75 \mathrm{c}$ & $4.59 \mathrm{c}$ \\
\hline IPB-013 & $3.54 \mathrm{c}$ & $1.12 \mathrm{~d}$ & $0.33 \mathrm{e}$ & $5.54 b$ \\
\hline IPB-014 & $1.77 \mathrm{a}$ & $3.71 \mathrm{c}$ & $1.21 \mathrm{~d}$ & $4.54 \mathrm{c}$ \\
\hline IPB-016 & $1.42 \mathrm{a}$ & $7.62 \mathrm{~b}$ & $1.75 \mathrm{c}$ & $8.11 \mathrm{a}$ \\
\hline IPB-023 & $1.50 \mathrm{a}$ & $2.62 \mathrm{~d}$ & $0.71 \mathrm{e}$ & $3.31 \mathrm{c}$ \\
\hline IPB-026 & $2.16 \mathrm{~b}$ & $2.12 \mathrm{~d}$ & $0.62 \mathrm{e}$ & $5.18 \mathrm{~b}$ \\
\hline IPB-027 & $2.34 \mathrm{~b}$ & $3.54 \mathrm{c}$ & $1.00 \mathrm{~d}$ & $6.74 b$ \\
\hline IPB-030 & $1.53 \mathrm{a}$ & $4.66 \mathrm{c}$ & $1.29 \mathrm{~d}$ & $6.34 \mathrm{~b}$ \\
\hline IPB-036 & $1.56 \mathrm{a}$ & $5.12 \mathrm{c}$ & $1.58 \mathrm{c}$ & $5.64 \mathrm{~b}$ \\
\hline IPB-037 & $1.61 \mathrm{a}$ & $5.12 \mathrm{c}$ & $1.62 \mathrm{c}$ & $5.90 \mathrm{~b}$ \\
\hline IPB-038 & $2.53 \mathrm{~b}$ & $3.87 \mathrm{c}$ & $1.25 \mathrm{~d}$ & $3.13 \mathrm{c}$ \\
\hline IPB-042 & $1.25 \mathrm{a}$ & $0.62 \mathrm{~d}$ & $0.33 \mathrm{e}$ & $2.06 \mathrm{c}$ \\
\hline IPB-043 & $2.73 \mathrm{~b}$ & $3.08 \mathrm{c}$ & $1.00 \mathrm{~d}$ & $3.11 \mathrm{c}$ \\
\hline IPB-047 & $2.27 \mathrm{~b}$ & $8.00 \mathrm{~b}$ & $1.71 \mathrm{c}$ & $4.70 \mathrm{c}$ \\
\hline IPB-052 & $1.17 \mathrm{a}$ & $4.50 \mathrm{c}$ & $1.12 \mathrm{~d}$ & $4.38 \mathrm{c}$ \\
\hline IPB-053 & $1.28 \mathrm{a}$ & $2.87 \mathrm{~d}$ & $0.79 \mathrm{e}$ & $5.25 \mathrm{~b}$ \\
\hline IPB-054 & $1.74 \mathrm{a}$ & $6.04 \mathrm{~b}$ & $1.83 \mathrm{c}$ & $5.60 \mathrm{~b}$ \\
\hline IPB-056 & $1.44 \mathrm{a}$ & $3.00 \mathrm{c}$ & $1.08 \mathrm{~d}$ & $5.90 \mathrm{~b}$ \\
\hline IPB-059 & $1.82 \mathrm{a}$ & $4.83 \mathrm{c}$ & $1.25 \mathrm{~d}$ & $3.62 \mathrm{c}$ \\
\hline IPB-060 & $1.77 \mathrm{a}$ & $1.83 \mathrm{~d}$ & $0.62 \mathrm{e}$ & $4.57 \mathrm{c}$ \\
\hline IPB-063 & $1.61 \mathrm{a}$ & $2.41 \mathrm{~d}$ & $0.66 \mathrm{e}$ & $6.18 b$ \\
\hline IPB-065 & $1.79 \mathrm{a}$ & $4.46 \mathrm{c}$ & $1.16 \mathrm{~d}$ & $4.98 \mathrm{~b}$ \\
\hline IPB-067 & $1.06 \mathrm{a}$ & $2.79 \mathrm{~d}$ & $0.96 \mathrm{~d}$ & $2.67 \mathrm{c}$ \\
\hline IPB-071 & $2.40 \mathrm{~b}$ & $11.00 \mathrm{a}$ & $2.70 \mathrm{a}$ & $8.10 \mathrm{a}$ \\
\hline IPB-072 & $2.66 \mathrm{~b}$ & $3.87 \mathrm{c}$ & $1.21 \mathrm{~d}$ & $5.48 \mathrm{~b}$ \\
\hline IPB-073 & $1.15 \mathrm{a}$ & $5.62 \mathrm{~b}$ & $1.66 \mathrm{c}$ & $5.40 \mathrm{~b}$ \\
\hline IPB-075 & $1.75 \mathrm{a}$ & $5.83 \mathrm{~b}$ & $1.54 \mathrm{c}$ & $5.74 \mathrm{~b}$ \\
\hline IPB-077 & $1.20 \mathrm{a}$ & $4.50 \mathrm{c}$ & $1.08 \mathrm{~d}$ & $5.36 \mathrm{~b}$ \\
\hline IPB-078 & $1.41 \mathrm{a}$ & $2.33 \mathrm{~d}$ & $0.75 \mathrm{e}$ & $2.29 \mathrm{c}$ \\
\hline IPB-079 & $1.31 \mathrm{a}$ & $3.08 \mathrm{c}$ & $0.87 \mathrm{~d}$ & $5.14 \mathrm{~b}$ \\
\hline IPB-087 & $1.62 \mathrm{a}$ & $4.58 \mathrm{c}$ & $1.25 \mathrm{~d}$ & $3.73 \mathrm{c}$ \\
\hline IPB-089 & $1.75 \mathrm{a}$ & $8.79 \mathrm{~b}$ & $2.29 \mathrm{~b}$ & $10.89 \mathrm{a}$ \\
\hline IPB-090 & $1.13 \mathrm{a}$ & $4.12 \mathrm{c}$ & $1.08 \mathrm{~d}$ & $5.40 \mathrm{~b}$ \\
\hline IPB-091 & $1.30 \mathrm{a}$ & $12.16 \mathrm{a}$ & $2.71 \mathrm{a}$ & $6.25 \mathrm{~b}$ \\
\hline IPB-093 & $1.70 \mathrm{a}$ & $3.08 \mathrm{c}$ & $0.79 \mathrm{e}$ & $3.97 \mathrm{c}$ \\
\hline IPB-095 & $1.17 \mathrm{a}$ & $4.83 \mathrm{c}$ & $1.42 \mathrm{c}$ & $6.05 \mathrm{~b}$ \\
\hline IPB-098 & $2.05 \mathrm{~b}$ & $6.58 \mathrm{~b}$ & $1.75 \mathrm{c}$ & $8.90 \mathrm{a}$ \\
\hline IPB-099 & $1.39 \mathrm{a}$ & $3.04 \mathrm{c}$ & $0.83 \mathrm{~d}$ & $5.38 \mathrm{~b}$ \\
\hline
\end{tabular}

continue 
Table 1. continuation

\begin{tabular}{|c|c|c|c|c|}
\hline \multirow[t]{2}{*}{ Accession } & \multirow{2}{*}{$\begin{array}{c}\text { Damages caused } \\
\text { by soil insects } \\
\text { (note 1-5) }\end{array}$} & $\begin{array}{l}\text { Shoot fresh } \\
\text { mass }\end{array}$ & $\begin{array}{c}\text { Shoot dry } \\
\text { mass }\end{array}$ & $\begin{array}{c}\text { Total root } \\
\text { productivity }\end{array}$ \\
\hline & & \multicolumn{3}{|c|}{ (t/ha) } \\
\hline IPB-101 & $1.27 \mathrm{a}$ & $5.16 \mathrm{c}$ & $1.41 \mathrm{c}$ & $5.10 \mathrm{~b}$ \\
\hline IPB-103 & $1.74 \mathrm{a}$ & $6.00 \mathrm{~b}$ & $2.12 \mathrm{~b}$ & $6.28 \mathrm{~b}$ \\
\hline IPB-105 & $2.73 \mathrm{~b}$ & $2.91 \mathrm{~d}$ & $1.08 \mathrm{~d}$ & $2.96 \mathrm{c}$ \\
\hline IPB-108 & $2.15 \mathrm{~b}$ & $1.50 \mathrm{~d}$ & $0.58 \mathrm{e}$ & $2.46 \mathrm{c}$ \\
\hline IPB-109 & $1.62 \mathrm{a}$ & $1.08 \mathrm{~d}$ & $0.58 \mathrm{e}$ & $3.57 \mathrm{c}$ \\
\hline IPB-113 & $1.56 \mathrm{a}$ & $2.45 \mathrm{~d}$ & $0.83 \mathrm{~d}$ & $3.43 \mathrm{c}$ \\
\hline IPB-114 & $1.41 \mathrm{a}$ & $1.71 \mathrm{~d}$ & $0.62 \mathrm{e}$ & $4.13 \mathrm{c}$ \\
\hline IPB-117 & $1.78 \mathrm{a}$ & $3.50 \mathrm{c}$ & $1.04 \mathrm{~d}$ & $5.62 \mathrm{~b}$ \\
\hline IPB-120 & $1.26 \mathrm{a}$ & $11.21 \mathrm{a}$ & $2.54 \mathrm{a}$ & $6.50 \mathrm{~b}$ \\
\hline IPB-121 & $1.96 \mathrm{a}$ & $3.29 \mathrm{c}$ & $0.83 \mathrm{~d}$ & $8.99 \mathrm{a}$ \\
\hline IPB-123 & $2.13 \mathrm{~b}$ & $0.96 \mathrm{~d}$ & $0.45 \mathrm{e}$ & $1.20 \mathrm{c}$ \\
\hline IPB-126 & $1.47 \mathrm{a}$ & $3.42 \mathrm{c}$ & $0.91 \mathrm{~d}$ & $5.28 \mathrm{~b}$ \\
\hline IPB-127 & $1.63 \mathrm{a}$ & $7.08 \mathrm{~b}$ & $1.66 \mathrm{c}$ & $6.35 \mathrm{~b}$ \\
\hline IPB-134 & $2.43 \mathrm{~b}$ & $3.95 \mathrm{c}$ & $1.16 \mathrm{~d}$ & $5.36 \mathrm{~b}$ \\
\hline IPB-136 & $1.06 \mathrm{a}$ & $2.66 \mathrm{~d}$ & $0.66 \mathrm{e}$ & $3.63 \mathrm{c}$ \\
\hline IPB-137 & $2.07 \mathrm{~b}$ & $3.37 \mathrm{c}$ & $1.00 \mathrm{~d}$ & $3.93 \mathrm{c}$ \\
\hline IPB-144 & $1.30 \mathrm{a}$ & $6.12 b$ & $1.79 \mathrm{c}$ & $4.36 \mathrm{c}$ \\
\hline IPB-145 & $1.36 \mathrm{a}$ & $5.33 \mathrm{c}$ & $1.46 \mathrm{c}$ & $5.13 \mathrm{~b}$ \\
\hline IPB-146 & $2.21 \mathrm{~b}$ & $0.45 \mathrm{~d}$ & $0.17 \mathrm{e}$ & $3.65 \mathrm{c}$ \\
\hline IPB-147 & $1.60 \mathrm{a}$ & $2.66 \mathrm{~d}$ & $1.00 \mathrm{~d}$ & $5.58 \mathrm{~b}$ \\
\hline IPB-148 & $1.51 \mathrm{a}$ & $1.16 \mathrm{~d}$ & $0.50 \mathrm{e}$ & $5.03 \mathrm{~b}$ \\
\hline IPB-149 & $1.18 \mathrm{a}$ & $4.73 \mathrm{c}$ & $1.29 \mathrm{~d}$ & $7.08 \mathrm{~b}$ \\
\hline IPB-150 & $1.33 \mathrm{a}$ & $2.00 \mathrm{~d}$ & $0.62 \mathrm{e}$ & $3.03 \mathrm{c}$ \\
\hline IPB-151 & $2.92 \mathrm{c}$ & $0.58 \mathrm{~d}$ & $0.29 \mathrm{e}$ & $2.17 \mathrm{c}$ \\
\hline IPB-153 & $1.35 \mathrm{a}$ & $3.08 \mathrm{c}$ & $0.92 \mathrm{~d}$ & $4.23 \mathrm{c}$ \\
\hline IPB-154 & $2.05 \mathrm{~b}$ & $1.70 \mathrm{~d}$ & $0.79 \mathrm{e}$ & $3.58 \mathrm{c}$ \\
\hline IPB-155 & $1.46 \mathrm{a}$ & $3.16 \mathrm{c}$ & $0.95 \mathrm{~d}$ & $3.23 \mathrm{c}$ \\
\hline IPB-157 & $1.66 \mathrm{a}$ & $2.67 \mathrm{~d}$ & $0.96 \mathrm{~d}$ & $3.37 \mathrm{c}$ \\
\hline IPB-158 & $2.21 \mathrm{~b}$ & $6.25 \mathrm{~b}$ & $1.54 \mathrm{c}$ & $4.52 \mathrm{c}$ \\
\hline IPB-159 & $1.22 \mathrm{a}$ & $7.33 \mathrm{~b}$ & $2.08 \mathrm{~b}$ & $3.31 \mathrm{c}$ \\
\hline IPB-160 & $3.22 \mathrm{c}$ & $1.08 \mathrm{~d}$ & $0.37 \mathrm{e}$ & $5.36 \mathrm{~b}$ \\
\hline Média & 1.78 & 4.18 & 1.16 & 5.01 \\
\hline CV (\%) & 18.18 & 29.14 & 22.58 & 26.59 \\
\hline
\end{tabular}

Averages followed by the same lowercase letters in columns did not differ among them, by Scott-Knott test ( $\mathrm{p} \leq 0.05)$. * Notes from 1 to 5 , where "1" represents damage-free roots and 5 totally unsuitable roots.

$13.7 \%, 9.6 \%, 9.6 \%, 8.2 \%$ and $1.3 \%$ of the accessions showed to be absent, toothed, triangular, semi-ellipitic, lanceolate and linear, respectively. The accessions showed different mature leaf size, considering $16.4 \%$ small, $80.9 \%$ medium and $2.7 \%$ large. In relation to the vein pigmentation $24.6 \%$ were green, $10.9 \%$ showed purple spot in the base of main rib, $23.3 \%$ showed main rib partially purple, $16.4 \%$ of the main rib were mostly or totally purple, $12.4 \%$ showed all the ribs partially purple and $12.4 \%$ with all the ribs mostly or partially purple. For the mature leaf color, $84.9 \%$ were yeloowish-green, $9.6 \%$ green and $5.5 \%$ slightly purple. Immature leaves of $20.6 \%$ of the accessions were green,
$53.4 \%$ green with purple edge, $1.3 \%$ grayish-green, $5.5 \%$ green with purple veins on upper surface, $5.5 \%$ slightly purple, $5.5 \%$ mostly purple, $5.5 \%$ green on the upper surface and purple on the lower surface of the leaves, and $2.7 \%$ purple on both surfaces. The authors noticed that $50.8 \%$ of the accessions showed very short petiole, $47.9 \%$ short and $1.3 \%$ intermediate. For petiole pigmentation, the authors observed green color in $19.2 \%$ of the accessions, green with purple near stem in $1.3 \%$, green with purple near leaf in $43.9 \%$, green with purple at both ends in $12.4 \%$, green with purple spots in $8.2 \%$, green with purple stripes in $1.3 \%$, some green petioles in $1.3 \%$, and purple or totally purple in $12.4 \%$.

Roots showed round shape in $2.7 \%$ of the accessions, round elliptic in $2.7 \%$, ellipitic in $12.4 \%$, ovate in $28.8 \%$, obovate in $5.5 \%$, oblong in $8.2 \%$, long oblong in $8.2 \%$, long elliptic in $9.6 \%$ and long irregular or curved in $21.9 \%$. The skin showed to be predominant white $(9.6 \%)$, cream $(20.6 \%)$, yellow $(1.3 \%)$, orange $(2.7 \%)$, brownish orange $(19.2 \%)$, pink $(26.1 \%)$, purple red $(9.6 \%)$ and dark purple $(10.9 \%)$. The intensity of the skin color was pale in $34.3 \%$ of the accessions, intermediate in $30.1 \%$ and dark in $35.6 \%$. The secondary skin color was absent for $78.2 \%$ of the accessions, cream (5.5\%), orange $(2.7 \%)$, brownish orange $(6.8 \%)$ and pink (6.8\%). The flesh color was mostly white in $30.1 \%$ of the accessions, cream in $41.1 \%$, dark cream in $13.8 \%$, pale yellow in $2.7 \%$, pale orange in $6.8 \%$, and strongly pigmented with anthocyanins in $5.5 \%$. In relation to secondary flesh color, about $97.4 \%$ was absent, $1.3 \%$ was purple and $1.3 \%$ dark purple. The authors also noticed that $6.8 \%$ of the accessions did not show deffects on the root surface, $45.2 \%$ showed alligator-like skin, $24.7 \%$ showed veins and $23.3 \%$ showed horizontal constrictions.

The morphological variability of the results obtained through hierarchical clustering analysis method of average distance between clusters of the accessions highlighted the existence of phenotypic variability. The authors observed two clusters, one with 16 


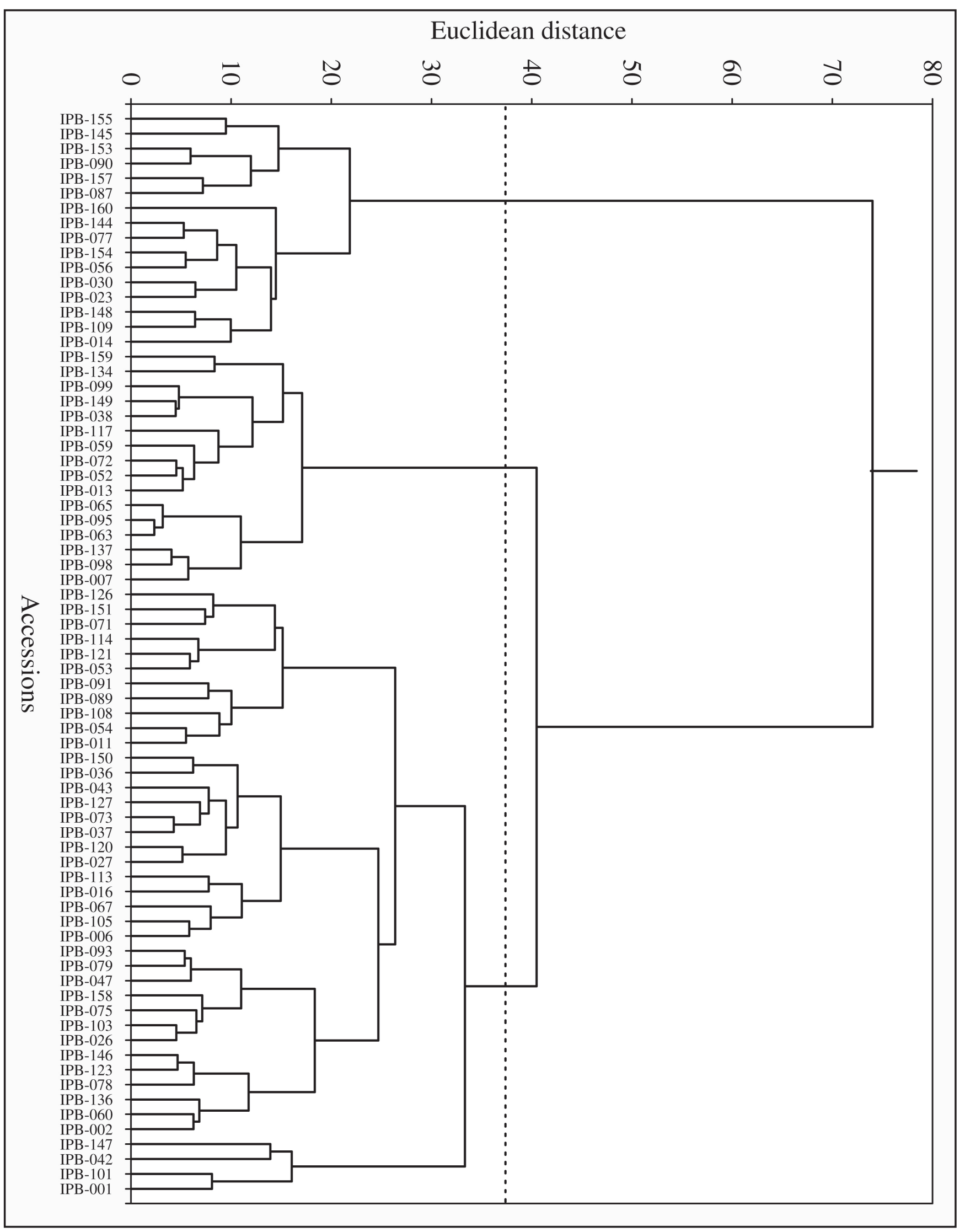

Figure 1. Morphological dissimilarity dendogram of 73 sweet potato accessions, established by UPGMA method, using Euclidean distance, based on 24 morpho-agronomic traits. São Cristóvão, UFS, 2012. 


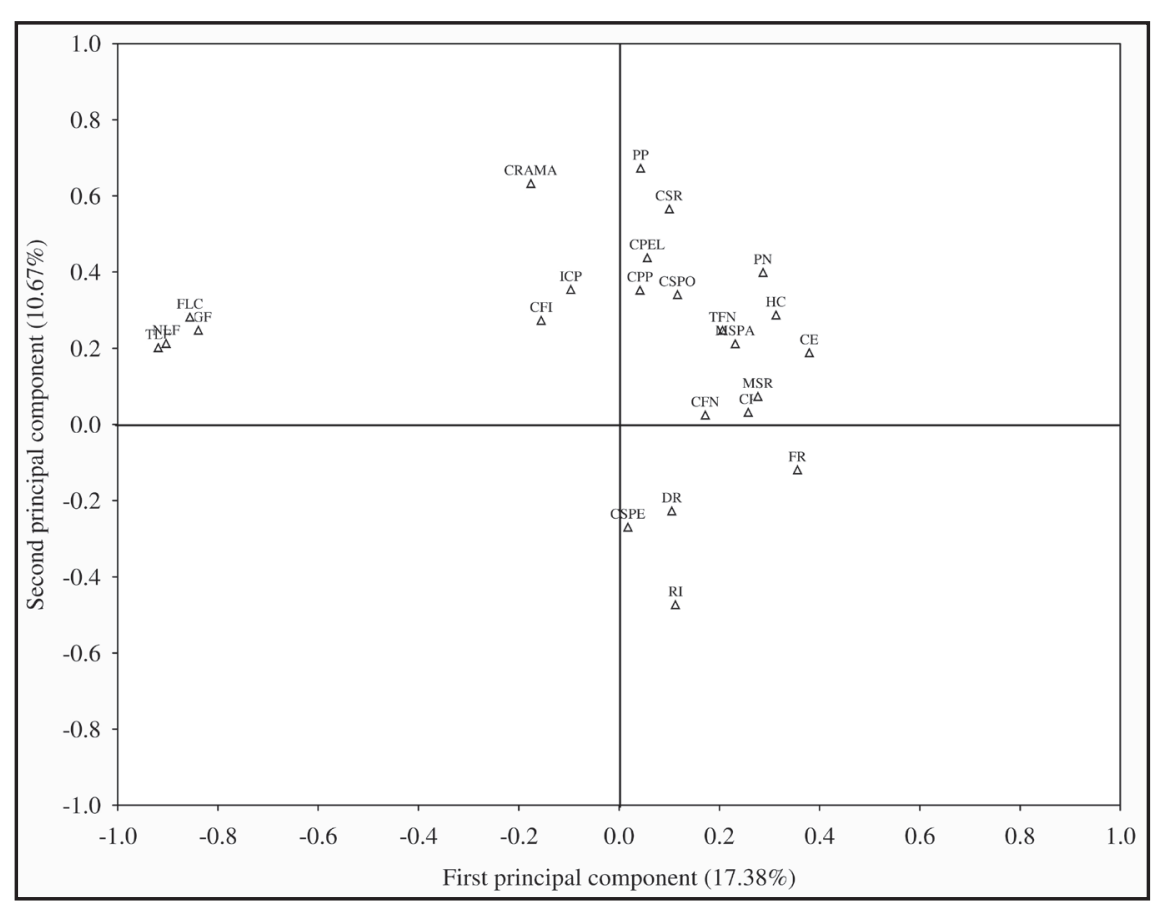

Figure 2. Dispersion graph of 24 morpho-agronomic traits $(\mathrm{HC}=$ growth habit, $\mathrm{CE}=$ internode length, $\mathrm{CRAMA}=$ predominant vine color, $\mathrm{CSR}=$ secondary vine color, $\mathrm{FGF}=$ general leaf shape, $\mathrm{TLF}=$ leaf lobe types, $\mathrm{NLF}=$ leaf lobe number, $\mathrm{FLC}=$ central leaf lobe shape, $\mathrm{TFM}=$ mature leaf size, $\mathrm{PN}=$ leaf vein pigmentation, $\mathrm{CFM}=$ mature leaf color, $\mathrm{CFI}=$ immature leaf color, $\mathrm{CP}=$ petiole length, $\mathrm{PP}=$ petiole pigmentation, $\mathrm{FR}=$ root shape, $\mathrm{CPEL}=$ predominant pellicle color, $\mathrm{ICP}=$ predominant pellicle color intensity, $\mathrm{CSPE}=$ secondary pellicle color, $\mathrm{CPP}=$ predominant flesh color, $\mathrm{CSPO}=$ secondary flesh color, $\mathrm{DR}=$ root surface defects, $\mathrm{RI}=$ damage caused by soil insects, MSPA= shoot dry mass, MSR= root dry mass of the sweet potato of the Germplasm Bank of UFS. São Cristóvão-SE, UFS, 2012.

accessions $(21.92 \%)$ and the other cluster composed of 57 accessions (78.08\%). The accessions IPB-001 and IPB-155 were the most divergent; on the other hand, the slightest divergence was observed in accessions IPB-095 and IPB-063 (Figure 1).

The authors could observe a great variability, without duplication of the accessions. The results found by Moulin et al. (2014) in Campos do Goytacazes-RJ identified five clusters with accessions morphologically duplicated; this was not observed in this study. When the authors characterized morphologically thirteen sweet potato accessions of the Active Bank of Embrapa Temperate Climate of Federal University (Pelotas), the formation of four clusters with subdivisions was verified (Silva et al., 2009).

The eigenvectors values show, in module, the order of importance and the contribution of the morphological descriptors for the variability of the studied group. Thus, in relation to descriptors used, the authors can state that for the first component (Y1), the most discriminating descriptors were: leaf lobe type (-0.919828), leaf lobe number $(-0.904024)$, shape of central lobe $(-0.856486)$ and general leaf shape $(-0.839520)$. In relation to the order of importance of the descriptors in the second principal component (Y2), the authors observed a change in

Dispersion graph was consistent with the values of eigenvectors for the first two principal components. The principal components analysis model with two principal components, explained $28.07 \%$ of the total variation. The primary principal component showing $17.39 \%$ and the secondary showing $10.68 \%$, separated variables leaf lobe type (TLF), leaf lobe number (NLF), central leaf lobe shape (FLC) and general leaf shape (FGF) of the other variables (Figure 2). contribution order.
The results found in this study were similar to the ones observed by Camargo (2013) in which the traits leaf lobe type (TLF), leaf lobe number (NLF), central leaf lobe shape (FLC) and general leaf shape (FGF), showed the highest values for relative contribution to phenotypic divergence of 40 sweet potato plant introductions. However, Elameen et al. (2011) observed that the traits which contributed the most for genetic divergence of 105 sweet potato accessions were root surface deffects, secondary pellicle (skin) color and secondary flesh color.

The information obtained through the principal component analysis allows identifying the most discriminating and informative morphological descriptors concerning studies on morphological characterization, allowing further studies related to morphological characterization of Ipomoea batatas, reducing and optimizing time for analyses (Yada et al., 2010).

For damages caused by soil insects, accessions showing lower notes are desirable, since they represent damagefree roots or roots showing little damage, suitable for market. Difference for this trait was observed through $\mathrm{F}$ test. The authors noticed a great variability in relation to the resistance of the genotypes to damage caused by soil insect, in which 52 accessions showed to be tolerant to insect attack and 21 were characterized as roots which are unsuitable for market. The accessions which showed the best averages can be used as donors of alleles which confer resistance to soil insects in breeding programs (Table 1).

Euscepes postfasciatus, known as West Indian sweet potato weevil, causes damage on the leaf surface, root and flesh, making the product unfeasible for commercialization (Bottega et al., 2009). When Silva (2010) evaluated 100 experimental accessions from botanical seeds of Universidade Federal do Tocantins, found an average value of 2.0 (roots showing little damage, losing a little regarding to the commercial aspect) degree of tolerance to soil pests for the accessions BDGU\#84, BDGU\#73 and Ana Clara cultivar. Higher average than the one found in 
this study, which was 1.78 .

For shoot fresh mass, the accessions IPB-091 (12.16 t/ha), IPB-120 (11.21 t/ ha), IPB-071 (11.00 t/ha) and IPB-011 (10.16 t/ha) showed the best yields. Data ranged from $12.16 \mathrm{t} / \mathrm{ha}$, for accession IPB-091, and $0.45 \mathrm{t} / \mathrm{ha}$, for IPB-146 (Table 1).

Green mass productivity from 2.3 to $41.7 \mathrm{t} /$ ha for clones CAJ-11 and CAL-3, respectively, are reported by Schumacher et al. (2012). Cavalcante et al. (2009) found values close to ours for shoot phytomass productivity of nine sweet potato clones and two varieties, ranging from 2.83 to $5.83 \mathrm{t} / \mathrm{ha}$. Andrade Júnior et al. (2012) observed productivity ranging from 7.3 to $19.7 \mathrm{t} /$ ha. Azevedo et al. (2014) found results similar to the ones found in this study, ranging from 5.50 to $10.25 \mathrm{t} /$ ha for green mass.

For shoot dry mass, the accession IPB-091 presented $2.71 \mathrm{t} / \mathrm{ha}$, showed the highest average and did not differ from the accessions IPB-071 (2.70 t/ha) and IPB-120 (2.54 t/ha). This variable showed average of $1.16 \mathrm{t} /$ ha (Table 1). Similar values were found by Oliveira et al. (2015), in a crop cycle of 150 days for the accessions IPB-007 and Brazlândia Rosada with 2.81 and 2.54 t/ha, respectively.

Concerning animal feed, fresh and dry masses of the shoot are important, since the sweet potato can be offered to birds and fishes in the form of fresh vines and for ruminants such as green forage and silage, being incorporated into cattle rations (Monteiro et al., 2007).

In relation to total root productivity, the authors found no difference among the accessions IPB-089, IPB-006, IPB121, IPB-098, IPB-016 and IPB-071, only IPB-089 (10.89 t/ha) showed productivity higher than $10 \mathrm{t} / \mathrm{ha}$ (Table 1). The values found in this study were lower than the Brazilian average productivity, which in 2013, reached $12.8 \mathrm{t} /$ ha (IBGE, 2013).

Evaluating eight sweet potato cultivars of the BAG of Universidade Federal Rural do Semi-Árido (UFERSA), Moreira et al. (2011) found values for total root productivity from 5.42 to $16.80 \mathrm{t} / \mathrm{ha}$. Whereas Roesler et al. (2008) report values from 6.76 to 8.04 t/ha. Cavalcante et al. (2009) evaluated productive and genetic potentials of sweet potato clones, with values for total root productivity from 4.17 to $12.08 \mathrm{t} / \mathrm{ha}$.

The sweet potato from the Active Germplasm Bank of Universidade Federal de Sergipe shows great phenotypic variability. Considering the different results for shoot fresh and dry mass productivity and total root productivity, the authors conclude that the accessions IPB-091, IPB-120, IPB071, IPB-011, IPB-089, IPB-006, IPB121, IPB-098, IPB-016 and IPB-071 may be used, for their high performance, aiming to increase crop productivity. On the other hand, the accessions IPB-007, IPB-013, IPB-151 and IPB-160, due to the high notes for damage caused by soil insects, should not be part of future sweet potato breeding programs.

\section{ACKNOWLEDGEMENT}

The authors thank to CNPq, FAPITEC/SE and CAPES for supporting the research. They also thank to Professor D. Wilson Roberto Maluf for making accessions of UFLA available for the experiment.

\section{REFERENCES}

ANDRADE JÚNIOR, VC; VIANA, DJS; PINTO, NAVD; RIBEIRO, KG; PEREIRA, RC; NEIVA, IP; AZEVEDO, AM; ANDRADE, PCR. 2012. Características produtivas e qualitativas de ramas e raízes de batata-doce. Horticultura Brasileira 30: 584-589.

AZEVEDO, AM; ANDRADE JÚNIOR, VC; VIANA, DJS; ELSAYED, AYAM; PEDROSA, CE; NEIVA, IP; FIGUEIREDO, JA. 2014. Influence of harvest time and cultivation sites on the productivity and quality of sweet potato. Horticultura Brasileira 32: 21-27.

BOTTEGA, BD; RODRIGUES, CA; PEIXOTO, N. 2009. Seleção de clones de batata-doce (Ipomoea batatas) resistentes a Euscepes postfasciatus em condições de campo em Ipameri, GO. Revista de Agricultura 84: 179-184.

CAMARGO, LKP. 2013. Caracterização de acessos de batata-doce do banco de germoplasma da Unicentro, PR. Curitiba: UFPR. 141p (Tese doutorado).
CAVALCANTE, M; FERREIRA, PV; PAIXÃO, SL; COSTA, JG; PEREIRA, RG; MADALENA, JAS. 2009. Potenciais produtivo e genético de clones de batata-doce. Acta Scientiarun 31: 421-426.

ELAMEEN, A; LARSEN, A; KLEMSDAL, SS; FJELLHEIM, S; SUNDHEIM, L; MSOLLA, S; MASUMBA, E; ROGNLI, OA. 2011. Phenotypic diversity of plant morphological and root descriptor traits within a sweet potato, Ipomoea batatas (L.), germplasm collection from Tanzania. Genetic Resources and Crop Evolution 58: 397-407.

FABRI EG. 2009. Diversidade genética entre acessos de batata-doce (Ipomoea batatas Lam) avaliada através de marcadores microssatélites e descritores morfoagronômicos. Piracicaba: USP-ESALQ. 172p (Tese doutorado).

FAO. 2010. Sistema de dados agrícolas atualizados. Disponível em: <http://faostat. fao.org/site>

FERREIRA, DF. 2011. SISVAR: um programa para análises e ensino de estatísticas. Revista Symposium 6: 36-41.

FIGUEIREDO, JA. 2010. Seleção de clones de batata-doce com potencial de utilização na alimentação humana e animal. Diamantina: UFVJM. 54p (Dissertação mestrado).

FILGUEIRA, FAR. 2008. Novo manual de olericultura. Viçosa: UFV. 402p.

FRANÇA, FH; RITSCHEL, PS. 2002. Avaliação de acessos de batata-doce para resistência à broca-da-raiz, crisomelídeos e elaterídeos. Horticultura Brasileira 20: 79-85.

GONÇALVES NETO, AC; MALUF, WR; GOMES, LAA; GONÇALVES, RJS; SILVA, VF; LASMAR, A. 2011. Aptidões de acessos de batata-doce para consumo humano, produção de etanol e alimentação animal. Pesquisa Agropecuária Brasileira 46: 15131520.

HUAMÁN, Z. 1992. Morphologic identification of duplicates in collections of Ipomoea batatas. Lima: International Potato Center. 28p. (CIP Research Guide, 36).

IBGE. 2013. 25 de novembro. Sistema de informação. Disponível em: ftp://ftp.ibge.gov. br/Producao_Agricola/Producao_Agricola_ Municipal_[anual]/2013/pam2013.pdf

MONTEIRO, AB; MASSAROTO, JA; GASPARINO, CF; SILVA, RR; GOMES, LAA; MALUF, WR; FILHO, JCS. 2007. Silagens de acessos e clones de batatadoce para alimentação animal visando sustentabilidade da produção agrícola familiar. Revista Brasileira de Agroecologia 2: 978981.

MOREIRA, JN; QUEIROGA, RCF; SOUZA JUNIOR, AJL; SANTOS, MA. 2011. Caracteres morfofisiológicos e produtivos de cultivares de batata-doce, em Mossoró, RN. Revista Verde 6: 161-167.

MOULIN, MM; BENTO, CS; SANTOS JUNIOR, AC; RODRIGUES, R. 2014. Caracterização de acessos de batata-doce baseado em 
características morfológicas. Perspectiva Online 13: 23-36.

OLIVEIRA, AMS; BLANK, AF; ALVES, RP; PINTO, VS; ARRIGONI-BLANK, MF; MALUF, WR. 2015. Características produtivas de clones de batata-doce cultivados em três períodos de cultivo em São CristóvãoSE. Horticultura Brasileira 33: 377-382.

ROESLER, PVS; GOMES, SD; MORO, E; KUMMER, ACB; CEREDA, MP. 2008. Produção e qualidade de raiz tuberosa de cultivares de batata-doce no oeste do Paraná. Acta Scientiarum Agronomy 30: 117-122.
SALAWU, IS; MUKHTAR, AA. 2008. Reducing the dimension of the growth and yield characters of sweet potato (Ipomea batatas L.) varieties as affected by varying rates of organic/inorganic fertilizer. Asian Journal of Agricultural Research 2: 41-44.

SCHUMACHER, PV; MOTA, JH; YURI, JE; RESENDE, GM. 2012. Competição de cultivares de batata-doce em Jataí-GO. Horticultura Brasileira 30: 2720-2726.

SILVA, JC. 2010. Performance agronômica de genótipos de batata-doce obtidos de sementes botânica com potencial para produção de etanol. Gurupi: UFT. 57p (Dissertação mestrado).

SILVA, GO; PEREIRA, AS; SOUZA, VQ; CASTRO, CM; CARVALHO, FIF; VIEIRA, EA. 2009. Distâncias genéticas entre genótipos de batata a partir de dados morfológicos, moleculares e genealógicos. Ciências Agrárias 30: 983-992.

YADA, B; TUKAMUHABWA, P; MWANGA, OM. 2010. Morphological characterization of Ugandan sweet potato germplasm. Crop Science 50: 2364-2371. 